\title{
Running Naked and Unmasked in Goa: Pleasure in the Pandemic
}

\author{
R. Benedito Ferrão
}

https://orcid.org/0000-0002-1160-8383

William and Mary, USA \& Bayreuth Academy of Advanced African Studies, Germany

\begin{abstract}
In November 2020, Indian celebrity Milind Soman posted a picture of himself on social media, which showed him running naked on a beach. He was charged with obscenity. This article considers the time and place of Soman's act over the alleged impropriety. The photograph was taken on a beach in Goa, the tropical setting serving as a pleasure periphery to India which annexed the region in 1961. Accordingly, a longer history of states of undress in Indian advertising, filmmaking, and tourism are considered here to apprehend how Goa has been posited in the Indian imagination as a destination for wanton self-gratification while local realities are undermined. The article thus interrogates what it means for Goa, whose economy is overly dependent on tourism, to serve as a vacation spot during the COVID19 pandemic, especially when, in 2020, it had among the highest number of virus-related deaths in the country (Dias, 2020, par. 4). Using the metaphor of the celebrity who has no qualms about running naked and unmasked in Goa, this article enquires into what such events leave unrevealed in the economic requirement that some locales function as holiday destinations, even in the midst of a pandemic.
\end{abstract}

Keywords: Goa, India, Economic Liberalisation, Tourism, Hippies, Bollywood, COVID-19 pandemic

eTropic: electronic journal of studies in the tropics publishes new research from arts, humanities, social sciences and allied fields on the variety and interrelatedness of nature, culture, and society in the tropics. Published by James Cook University, a leading research institution on critical issues facing the world's Tropics. Free open access, Scopus Listed, Scimago Q2. Indexed in: Google Scholar, DOAJ, Crossref, Ulrich's, SHERPA/RoMEO, Pandora. ISSN 1448-2940. Creative Commons CC BY 4.0 free to download, save and reproduce. To cite, include: Author(s), Title, eTropic, volume, issue, year, pages and DOI: http://dx.doi.org/10.25120/etropic.20.1.2021.3789 
eTropic 20.1 (2021) Special Issue: Pandemic, Plague, Pestilence and the Tropics

\section{Birthday (Suit) in Paradise}

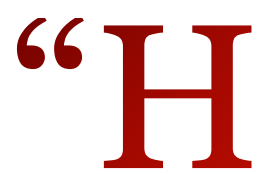

appy Birthday to me!" Milind Soman's Instagram post reads on 4 November, 2020. In it, the Indian model and actor is seen running on a beach in Goa while on holiday, (un)dressed for the occasion in his birthday suit. While it is apparent in the photograph (which the post credits his spouse Ankita Konwar for taking) that Soman is indeed naked, the camera catches him midstride, genitalia obscured. Reaction to the social media post oscillated from admiration for the still-fit-at-55 celebrity (Fernandes, 2020), to defense of his freedom of expression (HT Entertainment Desk, 2020b), to a charge of obscenity being brought against him (de Souza, 2020). All of these reactions had more to do with the person, Soman, rather than the place, Goa, where the celebrity indulged his whims. Although the alleged impropriety of nudity is a subject this article will engage with, my greater concern is with what Soman's nakedness does not reveal, particularly in the midst of the ongoing Coronavirus pandemic and especially in relation to the tourism destination of Goa. As revealed by the now infamous photograph, it is not only Soman's body that is uncovered in the picture, but also his face - he appears unmasked while on a public beach, abstaining from the use of that most commonplace piece of protection against the Coronavirus. A fitness enthusiast, Soman has declared that his interest in physical self-improvement began with his participation in an organisation that supports rightwing Hindu nationalism in India; Soman has stated that he saw his time as a youth with this group as simply being an extension of middle-class life and an opportunity to practice physical fitness (Mojo Story, 2020). Such nonchalance undermines the polticised links between class and caste in India which are also seen, in Soman's explanation, to be connected to bodily upkeep. Known for running regularly in his home city of Bombay/Mumbai (MW Staff, 2013), one would be hard-pressed to imagine the man taking a jog down one of the crowded streets of his native town unmasked and without a stitch of clothing on, especially given his politics.

Indeed, it is Goa, or some skewed idea of it, that apparently makes it possible for visitors to act differently in the tropical locale than they would elsewhere. Following Nina Rao's (1996) articulation of how developing nations turned to tourism for revenue-generation, making them pleasure peripheries to the first world (especially to pay down - albeit never able to pay off - international debts), Paul Routledge believes of Goa that India has made this tropical beach location "one of the world's pleasure peripheries, a cultural space for the leisure consumption of tourists divorced from the needs and concerns of everyday life" (2000, p. 2652). And even as Goa was positioned by the Indian government to serve as a site of pleasure for Western tourists, the resulting presence of white bodies in Goa, in addition to marketing strategies that draw "upon the state's [Portuguese] colonial past .... [allows] Goa [to be] viewed from within ... India as a cultural 'other'" (Routledge, 2000, p.2652). Presented as such to 
domestic Indian tourists, the image created of a Goa that is "exotic, easy going, westernised, promiscuous, and alcoholic" (Routledge, 2000, p.2652) sets the former Portuguese colony as a pleasure periphery to India where, seemingly, anything goes, even while a pandemic continues to rage.

Figure 1. Pandemic Paradise

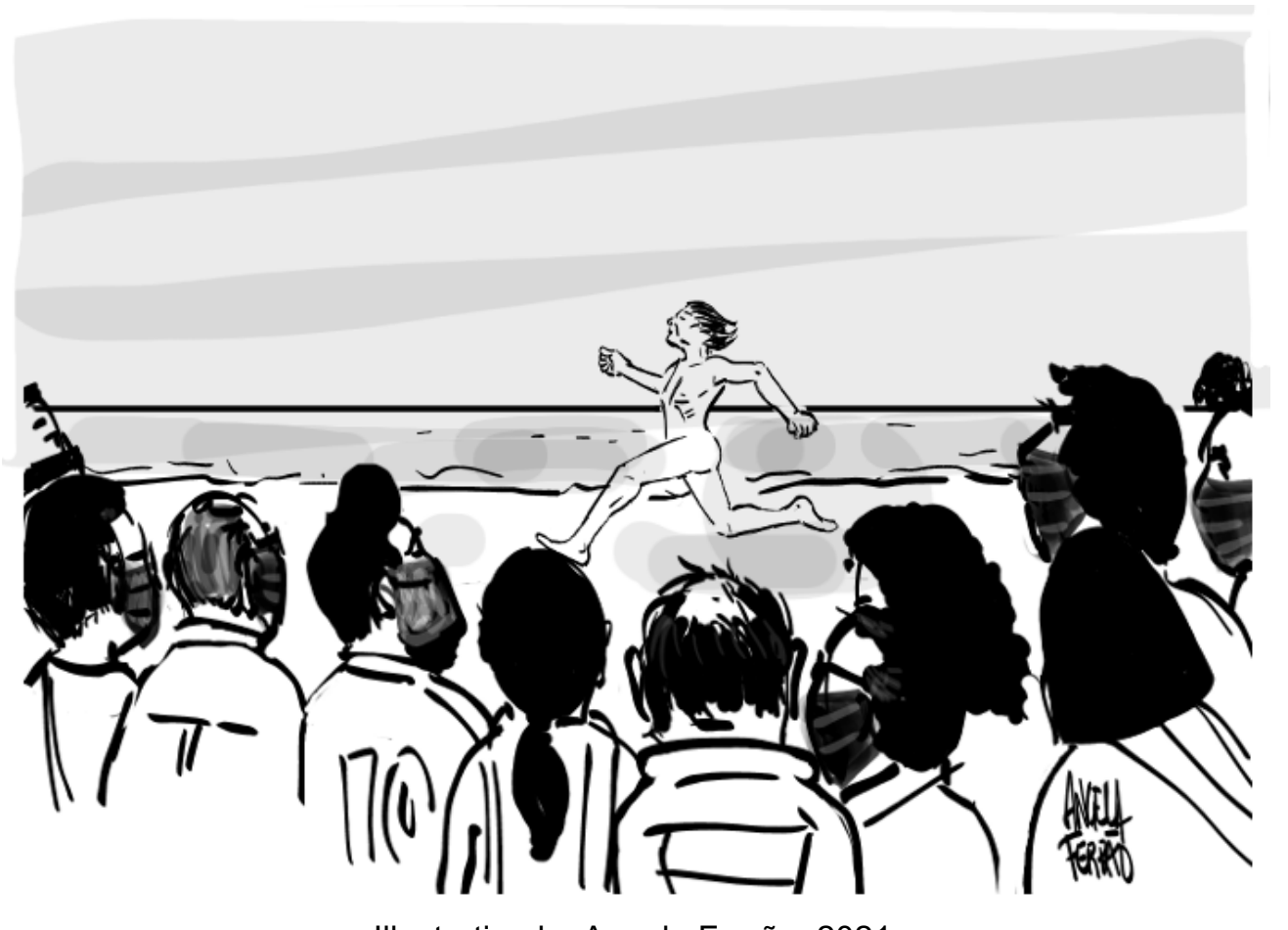

Illustration by Angela Ferrão, 2021.

Viewing Soman's career as an advertising model within the trajectory of the liberalisation of India's economy, a governmental move that was made in the early1990s, my article will also consider how Goa came to be imagined, culturally and socioeconomically, as a holiday destination for Indians in this period. Yet, tracing the history of holidaying in Goa from the previous century, I additionally contemplate how the region has played a role in the politicised escapism of hippies at one extreme and the pursuit of leisure for Indians in the post-liberalisation era on the other. Nonetheless, in both cases, I apprehend how notions of bodily display have meant, or come to mean, different things - freedom for hippies versus self-care for Indians - and how Goa has served as the locale for these manifestations of identity-making. That such self-expression is gendered is germane to my discussion of how visual cultures that display bodies in various states of undress, borne of advertising, Indian cinema, and social and other media, have come to fix Goa as a tropical holiday destination historically and in the economic relations between the region and the country, leaving little room for the diversification of Goa's economy. My thoughts on how a recursive, intermediated, and multi-generic visual culture have shaped Goa's economic fortunes as a site for tourism are in keeping with Routledge's understanding of how 
eTropic 20.1 (2021) Special Issue: Pandemic, Plague, Pestilence and the Tropics

Goa is imaged as a place of ... permissiveness, ... a terrain upon which tourists can project their fantasies, and do whatever they want, unconstrained by their own society's social mores ... Indian tourists [view Goa] as a carefree place where males can indulge in sexual behaviour that would be prohibited elsewhere in India. (2000, p. 2652)

That Goa, a Portuguese colony from 1510, was annexed by India in 1961, thirteen years after the latter's own independence from the British, heavily inflects the colonial relationship I trace between the two. It is especially this power differential, undergirded by history and economics, that I centre as the cause for the unrelenting presence of Indian tourists in Goa even as this state "has the highest number of deaths per million in India" in the wake of the Coronavirus pandemic (Dias, 2020, par. 4). As a celebrity tourist running naked and unmasked on a Goan beach, Soman's act allegorically represents the freedom Indians feel in Goa while it simultaneously covers up any revelation of how the pandemic has affected the local populace.

\section{The History of Holidaying in Goa}

As will be laid bare, nakedness is an integral part of how Goa came to be a tourism destination. Yet, this is a story that begins far away from the shores of the Konkan tropics; it has its roots in the discontent of a generation of youth in mid to late-1960s' America - the hippies. At first, Timothy Miller reckons in The Hippies and American Values, that the alienation young people were feeling during this period resulted "not so much [in] a confrontation with mainstream culture as a simple withdrawal from it ... Withdrawal often meant heading for a hip commune" (2011, p. xviii). Although

[t]he widespread sense of the counterculture was that ... dominant American culture ... had become a series of meaningless institutions that transcended persons and developed lives of their own[,] ... even dropping out was hard to do. Hippie communes were not welcome in many neighborhoods. (Miller, 2011, p. xviii)

This resulted in disenfranchised young hippies looking elsewhere to disconnect from American cultural values, the East becoming a much-craved destination. However, this desire to separate from one's society was not novel, Miller notes, the very history of the mythic "founding" of America having been reliant on those "early European settlers ... who saw themselves as having to withdraw from society and head for the wilderness to find satisfaction" (2011, p. 108). 
eTropic 20.1 (2021) Special Issue: Pandemic, Plague, Pestilence and the Tropics

In The Return of the Vanishing American, Leslie Fiedler contends with the early modern European entry into the lands of America's First Peoples, Native Americans, characterising this trespassing by whites as a search for the "radically alien other, an Indian" (1968, p.24). This tryst was meant to bring about "a metamorphosis of the WASP into something neither White nor Red (sometimes by adoption, sometimes by sheer emulation, but never by actual miscegenation), or else to the annihilation of the Indian" (Fiedler, 1968, p.24). Indeed, as Ned Blackhawk points out, the story of the creation of the United States cannot be understood without including the encounter between whites and Native people: "U.S. history and American Indian history must be understood together and as mutually interanimated" (2007, p. 1166). With the Americas conquered, whites needed to look elsewhere for renewal, a search for new others that transforms "the woodman which the ex-European becomes ... [into] the hunter, the trapper, the frontiersman, the pioneer, [and] at last the cowboy - or maybe next-to-last, for after him comes the beatnik, the hippie, one more wild man" (Fiedler, 1968, p. 25).

Fiedler's apprehension of transformativity, desired by whites as the product of European contact with Native Americans, is replete with the (stereotypical and) homogenising language of the 1960s (and earlier) in its description of America's First Peoples. The use of the misnomer "Indian," which has been reinterpretively adopted by Native peoples (Blackhawk, 2007, p. 1166), connotes the origins of the term from Columbus' erroneous Westward journey in search of the Indies. Synchronously, it links how the geographically distant lands of the Americas and South Asia came to be colonised by European oceanic expeditions. Even though Columbus had lost his way while looking for the Indies, the globe "is mythologically as well as geographically round; West becomes East, our whole vast land ... a Passage to India," muses Fiedler (1968, p. 27).

In so saying, Fiedler demonstrates the continuity of white Euro-American selfexploration as a metaphorical and physical journey that has continually relied upon seeking an elsewhere, the European "discovery" of America no different from the hippies' foray into India. The mid-twentieth century journey to the East, Arun Saldanha writes, is telling of the cultural milieu where the "love of India of Jack Kerouac, Allen Ginsberg, George Harrison, and ... their fans said as much about their own whiteness as about India. Sixties exoticist imaginations of India are but one instance of a wider yearning of adventurous whites to ... attain otherness" (2007, p. 19). And although it is true that hippies made their way to South Asia to find themselves, what has often been left out of the record is how this moment was also transformative for those on the receiving end of this encounter between West and East. The sixties was not only an era of change for the West; in Goa, it was the moment during which Portuguese colonialism ended and the tiny region was annexed by India in 1961. 
eTropic 20.1 (2021) Special Issue: Pandemic, Plague, Pestilence and the Tropics

Apart from its transference between Portugal and India, another major change that took place in Goa at this time, had as much to do with challenging caste hierarchies as it did feudalism. The Goa, Daman and Diu Agricultural Tenancy Act of 1964 owed much to the leadership of Goa's first post-Portuguese era Chief Minister. As Parag Parobo outlines in India's First Democratic Revolution: Dayanand Bandodkar and the Rise of Bahujan in Goa,

[t]he story of land reforms in Goa is unlike that of other states ... [T] he crucial difference was the social dynamism of the [newly elected] government. Implemented by Chief Minister Dayanand Bandodkar, who was of lower caste origins and a capitalist, land reforms were designed to destroy the upper castes' dominance based on land. (2015, pp. 145-146)

Dating their arrival at two years after the promulgation of the Tenancy Act, Raghuraman Trichur says of the hippies (not all of them only American) that came to Goa in 1966 by way of Nepal, that their inadvertent hosts were the Kharvis, a fishing community who "belonged to the lowest rung of the Catholic community in Goa" (2013, pp. 101-102). Trichur explains that, instead of turning into informal hospitalityproviders, the Kharvis should have benefitted from the recently instituted Tenancy Act which had given them ownership of the plots of land they had traditionally lived off in exchange for services rendered to their feudal landlords (2013, p. 101). Nevertheless, their "abject marginalization and poverty" kept them from reaping the benefits of these legal changes while the advent of the commercialisation of fishing was also beginning to cut into their traditional livelihoods (Trichur, 2013, pp. 101-102).

Accordingly, the Kharvi community used their residences by the sea "to earn extra money" (Trichur, 2013, p. 103), as Goan beaches became the preferred destination for hippies who presumably wished to commune with nature. That this included nudism was a carryover from their countercultural rebelliousness, a trait associated with their "new sexuality" as much as a symbolic freeing from (and protest against) mainstream US societal mores (Miller, 2011, pp. 30-31). Being naked and one with nature in Goa is reminiscent of Fiedler's observation of how the ex-Europeans went to the wilds of America to reinvent themselves, the adventure-seeking woodman thereupon becoming, in turns, the pioneer, the cowboy, and then the India-bound hippie. The Kharvis would then, presumably, have had to parallel what Natives had been to whites in America: an autochthonous and unchanging other. Due to their simple lifestyles, their coast-bound livelihoods, and attire suited to seafaring activities and coastal life, Kharvi people may have readily matched the image of what hippies expected of a people native to this eastern destination. Trichur conveys that the Kharvi hosts knew 
eTropic 20.1 (2021) Special Issue: Pandemic, Plague, Pestilence and the Tropics

exactly what beliefs their guests projected onto them, "that the hippies viewed them as poor and primitive" (2013, p. 103). This notwithstanding, the hippies did not interact with Kharvis with casteist prejudice and the economic exchange between them allowed members of this fishing community to achieve a greater degree of economic and social mobility than prevailing circumstances permitted (Trichur, 2013, p. 103). This being the case, Trichur concludes from his interviews with Kharvi people that they largely left the hippies to their ways, their co-existence being mutually beneficial.

Figure 2. Escape to Goa

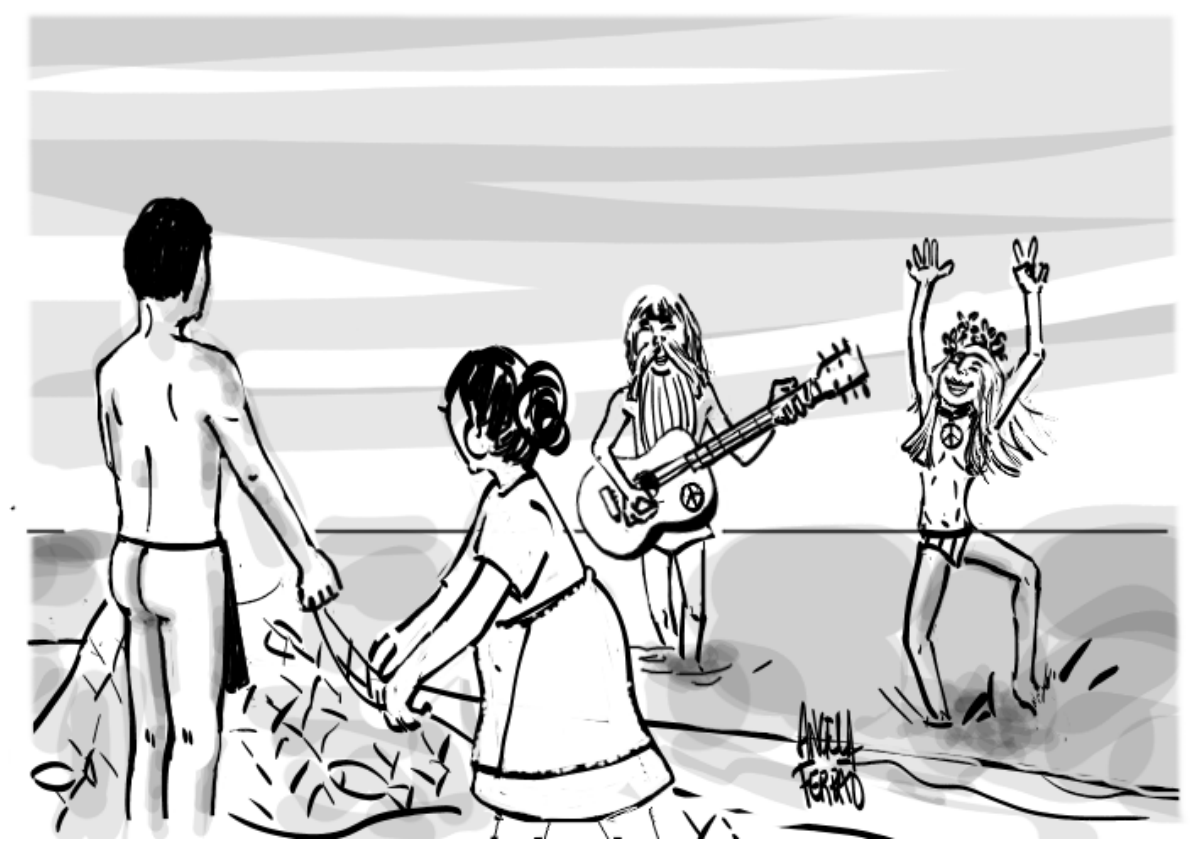

Illustration by Angela Ferrão, 2021.

From these humble beginnings, tourism in Goa burgeoned into an industry. The enterprising Kharvi community leading the way for others on Goa's coastal belt to model their home businesses after. With more hippies arriving in the 1970s, the need for lodgings increased. Government loans in that decade, and the next, allowed for the further growth of tourism, this also being the time during which Goa got what Trichur classifies as its "first capital-intensive beach resort" (2013, pp. 105-106). Operated by a (non-Goan) Indian-origin international conglomerate, the Fort Aguada Beach Resort signaled an irrevocable change in Goan tourism. This resort heralded the overtaking of Goan beaches by hotels of various styles and star-classifications. Multinational hotel chains became a mainstay. By the 1990s, Goan tourism found itself firmly within the grasp of the nation's neoliberal political economy. As Routledge apprehends, the nineties were named "the decade of tourism" by the Indian government, following its "Eighth Plan (1992-97) [which] argues that tourism contributes substantially to foreign exchange earnings and that the future expansion of tourism should be mainly through the aggressive promotion of luxury tourist 
eTropic 20.1 (2021) Special Issue: Pandemic, Plague, Pestilence and the Tropics

developments through the private sector" (2000, p. 2648). These initial strategies may have been directed at attracting foreigners but, with the liberalisation of the Indian economy, drew Indian tourists to Goa, too. Goa, which had once been a beach enclave that brought together a local fishing community and the West's disenfranchised youth, would, in the decades following its annexation, turn into India's playground, a site for its nakedly brazen excess.

\section{Liberalisation: Of Economy and Body}

Ironically, Goa's former status as a refuge for the anti-establishment hippies led to the advent of commercialised tourism which, since the liberalisation of the country's economy in the 1990s, has brought in hordes of tourists from within India - celebrities like Milind Soman included. In addition to its coastal location, while Goa was geographically (and, since its annexation, politically) part of India, what made it desirable to Indians was its difference from India, its Iberianisation the result of having been a Portuguese colony for nearly 500 years (Kandolkar, 2020). The liberalisation of India's economy put Goa within the reach of Indians looking for a nearby holiday destination. As Rekha Datta elucidates, liberalisation was a "watershed moment for India ... [T] he country was going through a culture shift ... By mid-1991, led by Prime Minister Narasimha Rao..., India introduced economic liberalization with a greater role of the market and reduced role of the state..." (2018, p. 105). But liberalisation did not only effect a cultural shift in the state's relationship with the economy, the resulting financial boom for some sections of the populace also affected their lifestyles. In an article for The New York Times titled “The Pirate Days are Over': Goa's Nude Hippies give Way to India's Yuppies," Maria Abi-Habib opines that the "concept of vacation is relatively new for many Indians, a product of the economic liberalization ... In a country of 1.3 billion, if just 1 percent of the population joins the middle class, that means 13 million more people with the ability to take vacations" (2019, pars. 11-12). Despite these financial and cultural changes, India's economy has only been showing "7 percent growth every year for the last 18 years [until 2019], ... [which] has directed the tourism internally, to places like Goa" (Abi-Habib, 2019, par. 13).

Apart from assuming lifestyle choices that included holidaying, self-attention became another avenue of expressing a sense of confidence imbued by economic change. In Muscular India: Masculinity, Mobility \& the New Middle Class, Michiel Baas (2020) makes the case for how the upsurge of opportunities borne out of India's new fiscal path in the nineties, also translated into a focus on fitness. Ajay Gehlawat more specifically ties the rise of a particular form of embodied masculinity to liberalisation in India by indicating how the new economy created a nexus between Bollywood, the national cinema, and commercial marketing which employed "metrosexual" film stars 
eTropic 20.1 (2021) Special Issue: Pandemic, Plague, Pestilence and the Tropics

whose bodies were gym-sculpted and often on display in films and advertisements of the period (2015, pp. 92-93).

Even as the Indian middle classes began to invest in fitness to express bodily confidence, inspired in part by Bollywood's male stars and the products they shilled by baring their bodies, holidaying in Goa was also part of this cultural and economic moment. Although a logical but rather glib connection could be made between Goa's location and its beaches being an apt place for Indian vacationers to engage in consumerist leisure that involves putting one's body on display in tropical weather, a more direct link is apparent, for cinematic and advertising industries paralleled Bollywood's setting of its films in Goa and the rise of the location as a preferred vacation spot for Indians. If this suggests that Bollywood advertised Goa to Indians, it did so by pandering to the conception that Goa was a pleasure periphery to the nation. As an example of such enticement, especially as it indicates how Goa began to factor into the Indian middle-class imaginary as a location for fulfilling impulses of masculine self-making through travel, I offer the case of a road-trip film set in a Goa with no Goans.

In a "listicle" for a travel magazine, Sarah Khan muses that "it's hardly a surprise that a beautifully shot Bollywood movie could have a major impact on a destination's tourism fortunes" (2020, par. 2). Connecting the cinematic with tourism and capitalism, the travel-writer goes on to remark of the Farhan Akhtar-directed Dil Chahta Hai that the "2001 movie ... depicting the lives of urban Indian youth ... [who] take a memorable road trip ... [to] Goa [has] inspired countless [other] similar road trips" (Khan, 2020, par. 11). That Dil Chahta Hai, a film of the road trip genre which signals a "journey of self-discoveries" (Baugh, 2020, p. 3) motivated a generation to make analogous excursions to Goa, brings to mind the earlier travels of hippies to the same destination to find themselves.

What distinguishes the trajectories of these two different sets of travelers is that the latter seek out Goa not to make a political, or even spiritual, statement, but as a site of consumptive leisure. Rejuvenated, their return to their jobs in the mainland reinscribes them as good economic middle-class citizens - unlike the hippies who shirked work and the war draft. Produced within a decade of India's economic liberalisation, Dil Chahta Hai stars actors Amir Khan and Saif Ali Khan, who Gehlawat (2015) inscribes as being physically fit metrosexuals who were as integral to Bollywood as to marketing campaigns. Linking advertising, holidaying, and film fantasy, the actors' shirtless bodies in Dil Chahta Hai are evocative of performatively proper masculinity. The friends' economic status is gestured at through their toned bare bodies while the film's resolution in the three finding heterosexual love abjures any threat of their homosociality possibly having any other meaning. In the meanwhile, 
eTropic 20.1 (2021) Special Issue: Pandemic, Plague, Pestilence and the Tropics

Goa serves solely as a setting at pivotal moments of the film, its locale being where Indian men of means take a break or work out life's dilemmas.

A place of pleasure, Goa in the film renders Goans themselves invisible - they are neither major characters in the storyline nor are the actors themselves Goan. Several other Bollywood films similarly set in Goa also establish a visual culture of beachholidaying that privileges Indian but not Goan subjectivity; where the films ostensibly have Goan characters, the roles are generally not played by Goan actors and the language medium is Hindi and not any of Goa's regional tongues, like Konkani or Marathi. Films of this ilk include the Golmaal series (2006-2010), Dum Maaro Dum (2011), Go Goa Gone (2013), and Dear Zindagi (2016) among others. In the decades following liberalisation, that Bollywood has "advertised" Goa as India's beach and party destination has resulted in a steady stream of tourists - even during the pandemic. Reporting on just this state of affairs in December 2020, Chryselle Dias remarks: "Tune into social media and you'll find 'mask-less' updates from actors, models, well-known journalists and other privileged folks from around the country who have escaped their homes ... to be 'safe' in Goa" (2020, par. 6).

In "'Almost Forgot COVID Existed': Confessions from Indians who Partied like there's no Pandemic," a tellingly titled article for Vice, Pallavi Pundir and Shamani Joshi interview several revelers who visited Goa to see out 2020. The views they recorded are but a small percentage of the four million people they believe came to the state at the end of the year (2021, par. 9). The conversations Pundir and Joshi had with New Year-partiers veer from the fearful, "It felt like a stampede waiting to happen. Nobody gave a flying fuck" (2021, par. 9) - to the hedonistic, "I partied every single day, at every different venue possible" (2021, par. 1). Somewhere in between, there appears some indication that there are those in Goa whose livelihoods are tourism-dependent and who bear the brunt of the cavalier attitudes of libertine merrymakers. As one interviewee recalls of their visit to a casino: "The staff was reminding people to wear masks" (Pundir \& Joshi, 2021, par. 10).

Pundir and Joshi's interviews, and the cynical tone in Dias' earlier mentioned article, stress the disjunction between the notion of all being well for tourists in Goa and the realities of locals. Most obviously, these tourists choose to remain oblivious to the high virus-related death toll in Goa (Dias, 2020, par. 4). Consider, too, that even the number of known infections and deaths in Goa might be unrepresentative of a fuller picture as "India has been witnessing underreporting and misreporting of COVID-19 cases" with "Goa ... among the 10 worst states for COVID-19 data reporting" (Pundir \& Joshi, 2021, par. 8). The revels of tourists in Goa at New Year's Eve and the social media posts by mask-less celebrities is indicative of the impunity with which visitors to Goa operate. Not only was the wearing of masks while outdoors made mandatory in the 
eTropic 20.1 (2021) Special Issue: Pandemic, Plague, Pestilence and the Tropics

region by governmental decree as early as April 2020 (a few weeks into the nationwide declaration of the pandemic), but fines were to be levied against those not complying with this requirement (PTI, 2020). In the face of such flouting of this pandemic-related law, Dias also pinpoints how the visuality of fun in Goa is recursively created and perpetuated via social media, just as is the case with Soman's use of Instagram to showcase his naked pleasure run on the beach.

Not strictly speaking a Bollywood star who could be placed in the same constellation as the aforementioned Khans, Soman's trajectory has nevertheless crossed over between modeling and acting. Traversing between the remits of marketing and entertainment industries in a career that put him in the public eye in the 1990s, as the next section will highlight, Soman's bare body has performed an essential role in demonstrating the relationship between the liberalisation of India's economy and the making of middle-class masculine identity. The episode I began with - Soman's unclothed romp on a Goan beach as viewed on social media - was not the first time he was seen in the altogether by the Indian public. Just as one can relate the growth of Indian tourism in Goa to the liberalisation of India's economy, a comparable link is to be made between the country's recent fiscal history and the little sagas of Soman's public nakedness. A gendered display, Soman's publicly bare-bodied legacy renders male privilege as middle-classness. Contrastingly, what the next section will take up is how women's bodies are differently positioned in relation to such identity-making.

\section{Forever Eve}

Pre-empting the later episode of being bare on the beach in Goa, in May 2020 Soman mused on social media about how his infamous 1995 footwear advertisement with Madhu Sapre would be received in the present day (HT Entertainment Desk, 2020a). The black-and-white photograph by Prabuddha Dasgupta, taken for the 1995 print advertisement, depicts Soman and Sapre cleaved to one another, a snake clinging to, and partially concealing, their chiseled nudity. Completing the Adam and Eve allusion, instead of fig leaves, the two are seen wearing only the sports shoes that the advertisement is for. That this advertisement for footwear would be a precursor for Soman's barefoot, naked, and unmasked run on a beach in Goa twenty-five years later also merits discussion of how the earlier image exemplifies the intersection between the country's economic liberalisation and resultant middle-class identitymaking through physical embodiment. While the advertisement feeds into the larger connections I have been making between the development of India's economy and its facilitation of a consumptive relationship between the country and Goa, connecting the two images of Soman's unclad appearance also uncovers the disjunction between the kinds of attention paid to men and women's bodies when they are on public display. 
eTropic 20.1 (2021) Special Issue: Pandemic, Plague, Pestilence and the Tropics

Deemed highly controversial at the time of its publication, it would take fourteen years for the two models to be acquitted of obscenity charges (HT Entertainment Desk, 2009). "This advertisement was, and still is, a landmark moment for Indian advertising," Tansha Vohra comments, adding that the attention it drew would have been multiplied further were it produced in the age of digital media (2017, par. 5). As already indicated, the featuring of physically fit bodies in advertising in India in the 1990s was emblematic of, catered to, and capitalistically inspired a generation that had begun to have more disposable income and were beginning to regard their own bodies as sites of investment. But what this particular advertisement did was to situate a woman's body within the imaginary of success and fitness in the era of liberalisation. While I previously mentioned Michiel Baas' book Muscular India: Masculinity, Mobility \& the New Middle Class in exploring how physical fitness came to be valued as part of middle-class identity-making in late-twentieth century India, as can be implied from the title, women's bodies are not its focus. Thereupon, what forms of agency might be seen in Sapre's nudity?

In scrutinising another famous nude image from the 1990s, that of the American actor Demi Moore as she appears, heavily pregnant, on the August 1991 cover of Vanity Fair, photographed by Annie Leibovitz, Imogen Tyler takes cognisance of how the "only items [the actor] is wearing in the image are diamond earrings and a large diamond ring.... The diamonds signify wealth, success, class and stardom" (2001, p. 74). Discounting the large snake wrapped around their bodies, the only garb Sapre and Soman sport in their advertisement are sneakers. Although clearly not as demonstrative of success as diamonds, athletic and casual wear had come to be associated with middle-class style in India, because of increased disposable income, an interest in fitness, and the desire to holiday (especially in Goa) amongst those of that echelon.

Given the crossover between advertising and entertainment industries, Bollywood films from the period can again be relied upon to evidence these style choices. Calling Bollywood "an important trendsetter," Ezrah Gilani credits the films Kuch Kuch Hota Hai (1998) and Kabhi Khushi Kabhie Gham (2001), both directed by Karan Johar, for popularising the casual clothing company GAP in India, because it "was the go-to brand for styling upper-class characters in [such] films" (2020, par. 2). The writer especially calls out Shah Rukh Khan's character's affinity for the label in Kuch Kuch Hota Hai, which "[created] a domino effect for wardrobe stylists on Indian film sets" (Gilani, 2020, par. 2). For Gehlawat, Shah Rukh Khan's position as "[o]ne of the first Bollywood stars to become a celebrity endorser in [the] new liberalized era" was in tandem with the "creation of [Khan as] a new type of Bollywood hero, the yuppie persona" who became the quintessential metrosexual of the nineties (2015, p. 92). 
eTropic 20.1 (2021) Special Issue: Pandemic, Plague, Pestilence and the Tropics

Thus, while Gehlawat places Khan's stardom in his ability to bridge Indian film and advertising industries, Gilani detects the role the star played in the kind of filmic product placement that made casual wear a middle-class mainstay. Gilani adds that the lasting impact of such efforts has been that even after two decades of the release of Kuch Kuch Hota Hai, street vendors are to be seen selling knockoffs of the GAP label in Colaba, a tony area of Bombay/Mumbai (2020, par. 4). In noting Khan's ability to promote a brand so effectively, that items of a particular brand of casual wear can connote middle-class success, speaks to the ability of celebrity, aided by film and advertising, to dictate taste and markers of achievement. In their 1995 advertisement, wearing nothing but the sneakers the image promotes, Soman and Sapre's athletic bodies draw attention to their confidence as subjects with the means to exercise and have time for leisure. So, although not jewels like the ones worn by Moore in her Vanity Fair cover, the shoes on the Indian models were still meant to resonate as symbols of class for the audience the advertisement was directed towards.

To this end, the image places Sapre and Soman, as a heterosexual couple (coincidentally partnered at that time), on par in terms of class standing, both toned and equally bare except for the identical shoes. In this regard, there is precedence to be found in Renaissance art. In "Gender and Shame in Masaccio's Expulsion from the Garden of Eden," James Clifton studies the appearance of the biblical first couple in Renaissance art:

Built into the Adam and Eve story - indeed essential to it - are both similarity (humanness) and opposition (male/female).... [S] he had to be like him ... enough to fulfill a role that the animals could not, but different from him enough to establish human sexuality and, by extension, human beings. Masaccio's Adam and Eve stride together in the same direction, both experiencing ... the same emotion, ... visible in gesture, as well as in anatomy. (1999, p. 641)

In the Eden-inspired footwear advertisement, Sapre and Soman together meet the gaze of the viewer, unashamed of their nudity.

A similar lack of shame would be in evidence decades later in Soman's Instagram photograph, where his uncovered appearance flagrantly advertises his appearance. This shameless self-promotion both balked laws linked to morality and safety advice related to the pandemic (i.e. wearing a mask), the brouhaha that followed further achieving the goal of keeping Soman's name in the headlines and securing his brand, as it were. Contrast Sapre and Soman's unabashed nudity with Tyler's likening of Moore's pregnant body to the virginal Madonnas of Renaissance paintings, meant to 
eTropic 20.1 (2021) Special Issue: Pandemic, Plague, Pestilence and the Tropics

be "devoid of sexual desire, as also evoked by "Moore's indeterminable gaze" (2001, p. 75). But unlike the Renaissance paintings of the Madonna, Moore's nudity causes

[h]er glowing white purity [to have] an ambivalent relationship to the sexuality her pregnant body simultaneously exudes ... If Moore had been shot directly returning the gaze of the spectator ... this image would have been more difficult to accept, as it would have been more readily interpreted as inappropriately sexually inviting. (Tyler, 2001, p. 75)

In contrast, looking directly into the camera, and also eliciting the biblical, Sapre's Eve is defiantly sexual as she is unembarrassed in meeting the viewer's gaze.

Such a depiction of Eve runs counter to representations of the biblical first woman in Renaissance art, even as "Edenic sexuality ... [is] a virtually unavoidable aspect of the story of Adam and Eve," Clifton declares (1999, p. 642). Explaining that the bible itself "gives little explicit indication of the emotions experienced by the primeval couple" at the time of their eviction from Eden, Clifton believes that "artists [took] recourse to their own imagination" to imbue their depictions of the couple with shamefulness and, in this, created a gendered difference in shaping the expression of such affect (1999, p. 642). Of Masaccio's fifteenth century work specifically, Clifton argues that the painter

responded to the implication that both Adam and Eve experienced shame at their nakedness - hence the iconographic requisite of their nudity.... A finer point may be made, however: that [their] gestures differ according to persistent, gender specific notions of shame; namely, that the man, as a primarily rational being, experiences intellectual (or spiritual) shame and thus covers his face (or head) as the seat of reason, whereas the woman, as a primarily carnal being, experiences sexual [or bodily] shame and thus covers her erogenous zones. (1999, p. 642)

Neither the differentiated shame of Masaccio's early-Renaissance art is to be seen in Sapre and Soman's bodily gestures in the advertisement, nor the gendered imbalance of such emotion, with Sapre's Eve placing her visible hand, not on her own body, but Soman's arm. But just as sexual and bodily shame came to be associated with the figure of Eve in Renaissance art, so too did Sapre experience the fallout of the footwear advertisement in different fashion from Soman.

Even though both models were charged with violating the Indecent Representation of Women Act, 1986, the very name of this law already connotes a lack of self- 
eTropic 20.1 (2021) Special Issue: Pandemic, Plague, Pestilence and the Tropics

representational agency on the part of women and infers, in its use, who of the two should be considered the more indecent party. Once the controversy abated, and perhaps even because of it, Soman continued to make a name for himself, going from being a model to an actor. In contrast, Sapre, who in 1992 had been the second runner up in the Miss Universe pageant as India's representative, saw her star fade until she fell out of the Indian entertainment industry entirely; she subsequently left the country and now lives in Italy (Sharma, 2016).

Writing about the November 2020 incident of Soman's alleged impropriety, legal expert Faisal Sherwani ascertains that Section 294 of the Indian Penal Code (IPC), 1860 , under which the celebrity was charged, is

from colonial times, with roots in the Victorian era. Section 294 of the IPC deals with obscenity, along with Section 292 and 293. The expression "obscenity", or what is "obscene" is not clearly defined in the IPC. In fact, Section 292 in its current form didn't exist in 1860, when the code was framed. It was inserted in 1925, so that makes it colonial, but yes with roots in the Victorian sense of puritanical existence.... There were fixed notions of what was "moral" and "acceptable." (2020, par. 3)

Of these Victorian ethics and their foundational role in creating the IPC, Anjali Arondekar holds that Lord Macaulay, who crafted the code, did so as much to make uniform a legal framework for governance across British India as to institute a secularised notion of morality to traverse the religious divides of colonial South Asia (2009, p. 77). In addition to the Indecent Representation of Women Act, Soman and Sapre had also been charged under Section 292(A) of the IPC, but as Sherwani (2020) sees it, the code is itself an unreliable source of gauging obscenity. "For a book or object to be obscene, Section 292 of the IPC says it must be lascivious or prurient or have the effect of depraving or corrupting someone," Shruti Sundar Ray offers, but also apprehends how '[t]he terms 'lascivious', 'prurient', 'deprave' and 'corrupt' have not been clearly defined, leaving room for interpretation by courts" (2020, par. 6).

The open-endedness of how obscenity is defined by the IPC may protect freedom of speech even as it restricts some expression of it (Ray, 2020, par. 11). But what remains questionable is why India retains a Victorian-era and colonially moralising set of laws (George, 2014). Further, that charges of obscenity affect the lives of women differently than they do men seems to be proven by the trajectories of Soman and Sapre's careers following the 1995 footwear advertisement and the resulting allegations of immorality. Twenty-five years later, that Soman was again charged for inappropriate conduct without a woman present in the frame of the image that went 
eTropic 20.1 (2021) Special Issue: Pandemic, Plague, Pestilence and the Tropics

viral on social media, may imply that the specter of immorality still always looms for men as well. But note that in the same week as Soman's naked run in Goa, Poonam Pandey, an Indian woman model and actor, was arrested for "shooting an 'indecent video"' while also on holiday in Goa ([Scroll.in] Staff, 2020, par. 2). The allegation of indecency also suggesting nudity, the content of Pandey's video has not been made publicly available in the way that Soman's Instagram post has, and yet, the charges brought against Soman did not result in an arrest, revealing what many Twitter users called out as a gendered double standard ([Scroll.in] Staff, 2020, par. 5-7).

Thinking through the liberalisation of India's economy and how it changed the consumerist habits of the Indian middle-class, both in their desire for beach holidays and moulding their bodies physically, I have been indicating how India's visual culture (which encompasses advertising, film, and social media) has spoken to and fed such identity-making processes. Within this, I have also highlighted how the legalities relating to displays of the body and impropriety can affect men and women differently. Using Soman as a subject whose public nudity has bookended the beginnings of India's economic liberalisation and the present moment, I have aimed to show how nudity sets into relief the pursuit of leisure and fitness as a marker of socioeconomic status. Attendant to this is the desire for holidaymaking, with Goa factoring into the Indian middle-class' imagination as a local pleasure destination especially because of the economic changes of the 1990s. Nevertheless, when women subjects present themselves in a fashion legally deemed obscene, the toll upon them is far greater than for their male counterparts, as I have pointed out in the cases of Sapre and Pandey in relation to Soman. Although Pandey, like Sapre, met a different fate than Soman alleged impropriety being the connection between them - that Pandey and Soman thought that Goa, in the midst of a pandemic, could serve as a place of such great escape that they could doff their clothes, and record the events, still bears further scrutiny.

\section{Goa without Goans}

In this concluding section, I want to return to the nakedness of the title of Abi-Habib's article, with its reference to Goa's yesteryears: “The Pirate Days are Over': Goa's Nude Hippies Give Way to India's Yuppies." The allusion in the headline is borne out by the anecdote the piece opens with, one about Elisabeth Ramnacher, a German woman who came to Goa in the 1980s and stayed on to run a café: "Yogini [Ramnacher's preferred name] wanted to show her employees what Goa used to look like back in its hippie days. The only trouble was, she couldn't find a picture of herself with clothes on" (Abi-Habib, 2019, par. 1). The journalist goes on to underscore how "the original countercultural community is now gone," due to a long lapse in time and economic changes; "[t]oday, Goa's renegade lifestyle attracts an entirely new type of 
eTropic 20.1 (2021) Special Issue: Pandemic, Plague, Pestilence and the Tropics

traveler - young Indians who are flocking here [but] not to find themselves, as the hippies once did" (Abi-Habib, 2019, pars. 4-5).

Abi-Habib's pronouncement may take stock of the changed demographics of Goa's sojourners, but in so doing cleaves the desires of the Indian yuppies from the erstwhile hippies and also divorces the alleged "lifestyle" of Goa from any connection it may have to the region's natives. In fact, although I have indicated how the liberalisation of India's economy made Goa the preferred holiday destination for the country's "yuppies," the Indian desire for Goa predates the 1990s and has much to do with the nudity of the now long-gone hippies. For instance, "The Goan Paradise" was the cover story of the 7 June, 1970 issue of the now defunct magazine The Illustrated Weekly of India. Focused on Goa, the issue contains several thematic articles, including a feature on Bandodkar, the then-Union Territory's first Chief Minister but, as the cover promises, the real draw is the beach paradise. An article titled "The Golden Sands of Calangute," which names a beach in Goa still popular with tourists, is short on story, relying heavily on several images of semi-clad white men and women ("Anzar," 1970, pp. 20-22).

In the picture-heavy piece, Naosherwan "Anzar" opens pithily: "To Goa and its wide stretch of beach have come flower children - from the world over. They spend their hours here, smoking charas, making love and discussing the Hereafter. Some Goans approve; some do not" (1970, p. 20). Stage set, "Anzar" goes on to interview the hippie characters the story is peopled with, their traits whittled down to a few defining phrases: Anne mentions her parents who are good people "[b]ut they are always at me. I can't do my thing;" Arthur, who "uses the word 'groovy' to describe nearly everything" declares that "LSD is groovy;" and Lucy, the rebel, who after being reported by the Dean of her school for attending an anti-Vietnam rally, was slapped by her mother and "walked out..." (1970, pp. 21-22).

Mise-en-scène adequately established, "Anzar" goes on to provide exegesis: "It is now proved that psychedelic drugs damage chromosomes and even cause mental derangement ... [T] hese flower children are attracted to hippiedom because of the freedom of sex ... [They] bear children without having solemnized a ritual wedding" (1970, p. 22). The moralising tone is inescapable, even as the dubiousness of whether "Anzar" actually conducted any interviews is matched by the questionable veracity of his generalised claims about "hippiedom." And titillation is never far, as when "Anzar" conveys Lucy's confession of her "sexual perversions ... 'My friends call me a 'queer' ... I like lan. He has beautiful vibrations. I like Sarah too. We like fondling each other. She now spends a lot of time with her baby'" (1970, p. 22). The anticlimax occurs with "Anzar"'s revelation of local disdain for the hippie's nudist ways, which even led to a complaint to the Chief Minister (1970, p. 22). 
eTropic 20.1 (2021) Special Issue: Pandemic, Plague, Pestilence and the Tropics

But in the denouement of this little story set in Goa, "Anzar" offers this beautiful vignette:

At Calangute, the beach reaches out to the sea as fishing boats leave their moorings and drift out to the vast expanse, just as the flower children watch the world drift by ... I return to the din of the city with my heart-strings still attached to the melody of nature that pervades the atmosphere at this land's end. (1970, p. 22)

At various turns, "Anzar" disavows the immoral, liberal, anti-establishment, and "queer" ways of the hippies, but then at other moments is drawn in by their lack of worldliness and detachment from middle-class institutional constraints. In closing, what "Anzar" perhaps unwittingly reveals, is not only a sense of attraction (in every sense of the word) for the hippies and their lifestyles, but also a desire to emulate this freedom that allows one to escape "the din of the city," that place of middle-class life. That "Anzar" locates this mystically salubrious place at "land's end," attaches Goa to, but away from, India, distanced as much by imagination as by cultural difference because of its Portuguese colonial past. Presented to the middle-class readership of The Illustrated Weekly of India, "The Goa Paradise" had to at once titillate with the promise of nude white bodies while diligently calling out their immorality. In all of this, "Anzar" makes scant mention of Goans themselves, hippies being the main draw and Goa being a paradise Indians could imagine as their own future getaway.

It would take the liberalisation of India's economy to fulfill the fantasy of coming to the paradise at land's end sketched out by the magazine. But the promise of nudity on Goan beaches never left the Indian imagination, even if the hippies had packed up and left decades before. On a regular basis, Goa's present Chief Minister finds himself having to negate claims that nude parties are commonplace in Goa (PTI, 2019). Aimed at Indian tourists, posters for such events promise the presence of "10-15 foreigners" in addition to Indian women at these nude events (PTI, 2019, par. 3). Perhaps related to this belief that Goa offers up the possibility of nudity, if not sex itself, it is not uncommon to hear of incidents of white women tourists being harassed on Goan beaches by men they describe as being Indian (Nair, 2020). Again, what such news coverage fails to address is why tourists from abroad and India continue to swarm Goa's beaches during a pandemic and, more to the point, do not address the safety of Goan locals, choosing instead to focus on the plight of visitors.

The lack of attention to the needs of Goans themselves is very much in keeping with the state's agenda when it comes to putting profits over people. Chryselle Dias conveys the thoughts of the Goan satirical cartoonist Angela Ferrão who says of the 
eTropic 20.1 (2021) Special Issue: Pandemic, Plague, Pestilence and the Tropics

state government's handling of tourism and the ongoing pandemic that it has "endlessly promoted Goa as just a setting ... They never mention the people who have created this beautiful vibe ... [Tourists think] everything goes here" (2020, par. 7). Commissioned by the government of Goa to envision a plan for the state's future as a tourism destination over the next twenty-five years, the multinational corporation KPMG unveiled its Tourism Master Plan (TMP) in 2016. Invested in bringing business from elsewhere into Goa, replete with the language of neoliberalism, the TMP delineates the role of Goans themselves as "'Hosts', [and] sets out how it will '[develop] training programs on customer service"' (Ferrão, 2016, par. 6). But, "what does it mean when a government-commissioned master plan only foresees the role of the people of its state as 'hosts' and not as entrepreneurs or innovators?" (Ferrão, 2016, par. 6). If KPMG's TMP is evidence of the Goan government's divestment of responsibility for tourism planning onto a corporation, then its handling of healthcare in the state equally demonstrates its failure to put the welfare of its own residents first. Mirroring the problems of the underfunded health care system in the country where, according to a World Bank study, "[a]t under 1 per cent of its GDP spent on public health, India ranks among the lowest globally," conditions at "Goa's state-run medical facilities ... [have been] worsened by [the] pandemic" (Ferrão, 2021, p. 123). Officially reopening Goa's border to tourists in the last quarter of 2020 , the Goan government did so as COVID19 infections in Goa were at "the highest percentage per million in the country" and the state's medical facilities were not capable of dealing with the onslaught (Menezes, 2020, par. 5).

"As a state that relies heavily on tourism revenues, December is an important month for the Goan economy. Particularly in a year when the state faced its steepest contraction, the party season became even more essential," write Pundir and Joshi, reflecting back on 2020 (2021, par. 14). Though Pundir and Joshi do not explicitly link the actions of the Goan government with an aim to ameliorate this economic decline, they take notice of how, in the lead up to New Year's Eve, the state resumed a flight schedule that was "near-normal" and that the Chief Minister announced there were no plans to "impose night curfew" when such limitations were in place elsewhere in India (2021, pars. 3-4). Despite their noncommittal inclusion of these pieces of information, Pundir and Joshi find it necessary to add that, as evidenced in India in 2020, "rising COVID-19 infections coincide[d] with the swift opening up of state borders and commercial activities" (2021, par. 6). Writing from Goa, Vivek Menezes echoes Angela Ferrão's sentiments about the government's lack of care for its residents, as well as the laissez faire attitude many tourists have on their visits to Goa:

A party destination at the best of times, the state is being overwhelmed by visitors during the pandemic who have scant regard for health and safety... 
eTropic 20.1 (2021) Special Issue: Pandemic, Plague, Pestilence and the Tropics

A vast majority of Goa's citizens agree that the state economy — like everywhere else - needed to get back on track. But they are appalled by how irresponsibly the gates were thrown open, with zero enforcement of the government's own stated precautions. (2020, pars. 1 and 15).

Continuing the lament about the current state of affairs in the region, Dias notes how masklessness amongst tourists is rife, with little done to enforce this simple precautionary measure $(2020$, par. 8$)$.

Also unmasked, when Soman stripped down on the beach in Goa and recorded the event on social media, his post was meant to suggest carefreeness. Occurring decades after the hippies had done the same thing in the same place, the celebrity's actions come across as an act of self-indulgence, especially as the pandemic takes so many lives in Goa. As the demographic of tourists coming to Goa has changed over the decades since its annexation by India, what has also altered is the role tourism has played in shaping India's economic and cultural relationship with Goa. Evidence of this is to be seen in various forms of media over the years, including film, advertising, print and online publications, and social media. Fixed as India's pleasure periphery, Goa's economy remains so beholden to tourism that it has prematurely thrown open its borders to holidaymakers while the pandemic continues. If twenty-five years ago, Soman's nudity and its outcome was a case study of gendered difference as India entered a new economic landscape, then the most recent episode of his unclothedness emphasises the ongoing consumptively hierarchical relationship between India and Goa, liberalisation and naked pleasures entwined. But in the midst of all seemingly laid bare, what goes unseen is the toll on the locale at land's end, a place catering to the pleasures of others as if it had no people and problems of its own. 
eTropic 20.1 (2021) Special Issue: Pandemic, Plague, Pestilence and the Tropics

\section{References}

Abi-Habib, M. (2019, February 17). "The Pirate Days are Over”: Goa's Nude Hippies Give Way to India's Yuppies. The New York Times.

https://www.nytimes.com/2019/02/17/world/asia/goa-india-tourism.html

"Anzar," N. (1970, June 7). The Golden Sands of Calangute. The Illustrated Weekly of India, 20-22.

Arondekar, A. (2009). For the Record: On Sexuality and the Colonial Archive in India. Duke University Press. https://doi.org/10.1215/9780822391029

Baas, M. (2020). Muscular India: Masculinity, Mobility \& the New Middle Class. Context.

Baugh, S. (2020). Y Tu Mamá También: Mythologies of Youth. Routlege. https://doi.org/10.4324/9781315114248

Blackhawk, N. (2007). Recasting the Narrative of America: The Rewards and Challenges of Teaching American Indian History. The Journal of American History, 93 (4), 11651170. https://doi.org/10.2307/25094606

Clifton, J. (1999). Gender and Shame in Masaccio's Expulsion for the Garden of Eden. Art History, 22 (5), 637-655. https://doi.org/10.1111/1467-8365.00180

Datta, R. (2018). Contemporary India: The Basics. Routledge.

de Souza, G. (2020, November 7). Milind Soman faces FIR, charged with obscenity for naked run on Goa beach. Hindustan Times. https://www.hindustantimes.com/indianews/milind-sonam-faces-fir-charged-with-obscenity-for-naked-run-on-goabeach/story-qNTXV5B9mxn0ccplDyddLI.html

Dias, C. (2020, December 4). What Goa's Locals want You to Know. The Hindu. https://www.thehindu.com/life-and-style/travel/what-goas-locals-want-you-toknow/article33250027.ece/amp/

Fernandes, B. (2020, November 4). Milind Soman shares a pic of him running nude on the beach on his $55^{\text {th }}$ birthday. Republicworld.com.

https://www.republicworld.com/entertainment-news/bollywood-news/milind-somanshares-a-pic-of-him-running-nude-on-the-beach-on-his-55th-birthday.html

Ferrão. R. B. (2016, October 16). Making Goans Servants to the Tourism Master Plan. The Goan Everyday. https://www.thegoan.net//making-goans-servants-to-the-tourismmaster-plan/24067.html

Ferrão. R. B. (2021). Disease and Discrimination in Goa: COVID-19 in the Afterlife of AIDS. Society and Culture in South Asia, 7 (1), 119-125. https://doi.org/10.1177/2393861720975113

Fiedler, L. (1968). The Return of the Vanishing American. Stein \& Day.

Gehlawat, A. (2015). Twenty-first Century Bollywood. Routledge. https://doi.org/10.4324/9781315761048

Gilani, E. (2020, August 22). The Bollywood and the Socio-Economic Impact of GAP in India. Brown Girl Magazine. https://browngirlmagazine.com/2020/08/bollywood-andthe-socio-economic-impact-of-gap-in-indial

George, J. (2014, June 1). Sex Toys and the Law - The Unexplored Opportunity. In Plainspeak. https://www.tarshi.net/inplainspeak/voices-sex-toys-and-law-theunexplored-opportunity/

HT Entertainment Desk. (2009, November 28). Milind Soman, Madhu Sapre Acquitted. Hindustan Times. https://www.hindustantimes.com/entertainment/milind-somanmadhu-sapre-acquitted/story-iemvUiKSHhvVPiVro3bDCJ.html

HT Entertainment Desk. (2020, May 18). Milind Soman shares Controversial Nude Photo Shoot from 25 Years ago, Wonders how it would be Received Today. Hindustan Times. https://www.hindustantimes.com/bollywood/milind-soman-shares- 
eTropic 20.1 (2021) Special Issue: Pandemic, Plague, Pestilence and the Tropics

controversial-nude-photo-shoot-from-25-years-ago-wonders-how-it-would-bereceived-today/story-nxSBq4AS5zJBbPljOWY9yL.html

HT Entertainment Desk. (2020b, November 9). Pooja Bedi defends Milind Soman's nude beach photo: "His crime is being good looking, famous and setting benchmarks". Hindustan Times. https://www.hindustantimes.com/bollywood/pooja-bedi-defendsmilind-soman-s-nude-beach-photo-his-crime-is-being-good-looking-famous-andsetting-benchmarks/story-BKtdhNAxme1Ob0PGApQXfK.html

Kandolkar, V. (2020). Consuming Goa Portuguesa: Vacationing in a Postcolonial Colony. Journal of Human Values, 26 (3), 266-276. https://doi.org/10.1177/0971685820940895

Khan, S. (2020, May 6). 11 Bollywood Movies we Love and Where to Watch Them. Condé Nast Traveler. https://www.cntraveler.com/gallery/bollywood-movies-we-love-andwhere-to-watch-them

Menezes, V. (2020, November 8). A Party Destination at the Best of Times, Goa Overwhelmed by Visitors during the Pandemic. Mumbai Mirror. https://mumbaimirror.indiatimes.com/others/sunday-read/go-goagone/articleshow/79103281.cms?fbclid=IwAR1 rxwoM LuAMkmacu922yBhEiBMUPE zhJDTc7VmWrWZ963GRwjVt-Si97E

Miller, T. S. (2011). The Hippies and American Values ( $2^{\text {nd }}$ ed.). The University of Tennessee Press.

Mojo Story. (2020, March 11). What Milind Soman said about the RSS and his Time in a Shakha. https://www.youtube.com/watch?v=9fCi2OFkwR8

MW Staff. (2013 November). Learning to run from Milind Soman. Man's World. https://www.mansworldindia.com/healthandfitness/learning-to-run-from-milindsoman/

Parobo, P. (2015). India's First Democratic Revolution: Dayanand Bandodkar and the Rise of Bahujan in Goa. Orient BlackSwan.

Press Trust of India. (2019, September 24). Person behind Poster for Nude Party in Goa "Tracked Down": Chief Minister. NDTV. https://www.ndtv.com/goa-news/pramodsawant-goa-chief-minister-on-goa-nude-party-poster-says-tracked-down-personbehind-it-2106395

Press Trust of India. (2020, April 24). COVID-19: Goa Govt makes Wearing of Masks Compulsory. The Economic Times of India.

https://economictimes.indiatimes.com/news/politics-and-nation/covid-19-goa-govtmakes-wearing-of-masks-compulsory/articleshow/75353438.cms

Pundir, Pallavi and Shamani Joshi. (2021, January 7). "Almost Forgot COVID Existed": Confessions from Indians who Partied like there's no Pandemic. Vice. https://www.vice.com/en/article/7k9eqz/india-covid-goa-party-rave-confessions

Rao, N. (1996). The Fourth Periphery and the Two Conventions. The Eye, 2 (4), 16-18.

Ray, S. (2020, November, 12). Explained: What is the Measure of "Obscenity" in India?. The Indian Express. https://indianexpress.com/article/explained/explained-milind-somanobscenity-in-india-6998750/

Routledge, P. (2000). Consuming Goa: Tourist Site as Dispensable Space. Economic and Political Weekly, 35 (30), 2647-2656.

Saldanha, A. (2007). Psychedelic White: Goa Trance and the Viscosity of Race. University of Minnesota Press.

Sharma, S. (2016, May 10). Mother's Day Special: Madhu Sapre's Fairy-tale Life in Italy. Hindustan Times. https://www.hindustantimes.com/brunch/mother-s-day-specialmadhu-sapre-s-fairy-tale-life-in-italy/story-io9yCpz4z5wyXVwvfKG95I.html

Sherwani, F. (2020, November 15). Milind Soman Booked for "Obscenity": History of Obscenity under Section 294, and how it is Defined. The Indian Express. https://indianexpress.com/article/explained/explained-history-of-obscenity-undersection-294-and-how-it-is-defined-7048062/ 
eTropic 20.1 (2021) Special Issue: Pandemic, Plague, Pestilence and the Tropics

Soman, M. [milindrunning]. (2020, November 4). Happy Birthday to me ! [Photograph]. Instagram https://www.instagram.com/p/CHJ5XC3HQT9/?hl=en

Staff. (2020, November 5). As Poonam Pandey is Arrested for "Obscenity" in Goa, Twitter asks why Model Milind Soman got Away. Scroll.in. https://scroll.in/latest/977776/aspoonam-pandey-is-arrested-for-obscenity-in-goa-twitter-asks-why-model-milindsoman-got-away

Trichur, R. (2013). Refiguring Goa: From Trading Post to Tourism Destination. Goa 1556.

Tyler, I. (2001). Skin-tight: Celebrity, Pregnancy and Subjectivity. In Sara Ahmed and Jackie Stacey (Eds.), Thinking through the Skin (pp. 69-83). Routledge.

Vohra. T. (2017, April 6). A Controversial NSFW Ad from 1995 that Created an Uproar. Homegrown. https://homegrown.co.in/article/800877/would-this-controversial-milindsoman-ad-from-1995-make-the-cut-today

\section{Acknowledgements}

My gratitude to Vishvesh Kandolkar, Samhita Sunya, and Deborah Al-Najjar for their insightful feedback and support during the process of writing this article.

This article is the outcome of research conducted within the Africa Multiple Cluster of Excellence at the University of Bayreuth, and was funded by the Deutsche Forschungsgemeinschaft (DFG, German Research Foundation) under Germany's Excellence Strategy - EXC 2052/1 - 390713894.

R. Benedito Ferrão is an Assistant Professor of English and Asian \& Pacific Islander American Studies at William and Mary (Virginia, USA) and a Fellow of the Africa Multiple Cluster of Excellence at Bayreuth Academy of Advanced African Studies (University of Bayreuth, Germany). He is the former recipient of a Fulbright-Nehru Research Award, a Mellon Faculty Fellowship, and an Endeavour Postdoctoral Fellowship. In 2017-18, he curated the exhibition Goa/Portugal/Mozambique: The Many Lives of Vamona Navelcar at the Fundação Oriente gallery in Panjim, Goa, and edited a book of the same title to accompany the retrospective (Fundação Oriente 2017). His scholarly writing has appeared, or is forthcoming, in Research in African Literatures, Middle East Journal of Culture and Communication, and Society and Culture in South Asia. An internationally published writer of fiction, non-fiction, and public commentary, Ferrão's work can be read in Scroll.in, The Wire, João Roque Literary Journal, and Mizna, among other publications. 